\title{
Severe Symptomatic Hyponatremia Due to Syndrome of Inappropriate Antidiuretic Hormone From Mild Closed Head Trauma and Concussion
}

\author{
Robert P. Henderson a, b, Paula A. Thompson ${ }^{\mathrm{a}}$
}

\begin{abstract}
We report the first published case of severe, symptomatic hyponatremia resulting from syndrome of inappropriate antidiuretic hormone (SIADH) incurred as the result of a blow to the head inducing a concussion without any additional signs of head injury. A 38-year-old male in excellent health suffered a fall from a tree causing a right leg fracture and blunt trauma to the head with concussion but no other signs of head injury. The patient was discharged several days after surgery for repair of his leg fracture and subsequently became severely ill with nausea, vomiting, headache, and seizures. He was readmitted with a serum sodium of $114 \mathrm{mEq} / \mathrm{L}(\mathrm{mmol} / \mathrm{L})$ with a presumed diagnosis of dehydration. After several days of saline administration he was discharged, but within 24 hours he again experienced severe, symptomatic hyponatremia and was admitted for the third time with a serum sodium of $110 \mathrm{mEq} / \mathrm{L}(\mathrm{mmol} / \mathrm{L})$. A diagnosis of SIADH was made, and the patient was successfully treated with fluid restriction, intravenous saline, and demeclocycline resulting in a full recovery without further incident. This case emphasizes the need to consider SIADH as a possible cause of severe hyponatremia in patients sustaining relatively minor closed head trauma.
\end{abstract}

Keywords: Hyponatremia; Syndrome; Antidiuretic hormone; Trauma; Concussion

\section{Introduction}

Hyponatremia may result from numerous types of intracranial insults, including cerebral hemorrhage, infections, brain tumors, neurosurgery, and severe head trauma [1-4].

Differentiation includes cerebral salt wasting syndrome

Manuscript accepted for publication December 02, 2014

aDepartment of Pharmacy Practice, McWhorter School of Pharmacy, 800 Lakeshore Drive, Samford University, Birmingham, AL 35229, USA

${ }^{b}$ Corresponding Author: Robert P. Henderson, Department of Pharmacy Practice, McWhorter School of Pharmacy, 800 Lakeshore Drive, Samford University, Birmingham, AL 35229, USA. Email: rphender@samford.edu

doi: http://dx.doi.org/10.14740/jmc2001w
(CSW) and syndrome of inappropriate antidiuretic hormone (SIADH). SIADH is a known sequelae of neurosurgical procedures and cases of severe head trauma with associated clinical findings of injury [1-8]. We report a case of severe, symptomatic hyponatremia from SIADH manifesting after a concussion with loss of consciousness but no other indication of head injury (e.g., skull fracture or abnormal MRI findings). The authors could find no similar case reported in the literature. With increased awareness, similar cases may be identified sooner and treated more appropriately.

\section{Case Report}

A 38-year-old male suffered a fall resulting in compound factures of the right fibula and tibia and blunt trauma to the occipital region of the head as evidenced by a mild abrasion. He reported loss of consciousness lasting approximately $20 \mathrm{~min}$. No other findings typically associated with head injury were found on physical exam. He conversed normally, only reporting pain associated with his leg fractures. A computerized tomography (CT) scan of the head was unremarkable with no evidence of skull fracture. The cerebral ventricles were normal in size and position without mass effect, and there was no high/low attenuation or intra/extra-axial lesions seen. On day 2, orthopedic surgery was performed, with screws placed in the tibia and a plate placed on the fibula to repair the fractures. Serum chemistries were within normal limits, including a $\mathrm{Na}$ of $139 \mathrm{mEq} / \mathrm{L}$ $(\mathrm{mmol} / \mathrm{L})$. The patient was placed on hydromorphone patientcontrolled analgesia (PCA) for pain control. Intravenous fluids were $\mathrm{D} 5 \mathrm{~W}+1 / 2 \mathrm{NS}$ at $150 \mathrm{~mL} / \mathrm{h}$ for approximately $12 \mathrm{~h}$ after surgery and $30 \mathrm{~mL} / \mathrm{h}$ thereafter. Nausea, attributed to narcotic administration, prevented the patient from taking in any fluids or nourishment. Nausea continued after the hydromorphone was discontinued, and it was still present at the time of discharge on day 4.

At home the patient became very ill with severe nausea, vomiting, and headaches culminating in a witnessed seizure on both days 5 and 6 . Upon readmission on day 6, serum chemistries revealed Na: $114 \mathrm{mEq} / \mathrm{L}(\mathrm{mmol} / \mathrm{L}), \mathrm{Cl}: 79 \mathrm{mEq} / \mathrm{L}$ $(\mathrm{mmol} / \mathrm{L}), \mathrm{K}: 4.4 \mathrm{mEq} / \mathrm{L}(\mathrm{mmol} / \mathrm{L}), \mathrm{CO}_{2}: 27 \mathrm{mEq} / \mathrm{L}(\mathrm{mmol} / \mathrm{L})$, BUN: $11 \mathrm{mg} / \mathrm{dL}(3.92 \mathrm{mmol} / \mathrm{L})$, Scr: $0.7 \mathrm{mg} / \mathrm{dL}(61.8 \mu \mathrm{mol} / \mathrm{L})$, cortisol $31.5 \mu \mathrm{g} / \mathrm{dL}(869.4 \mathrm{nmol} / \mathrm{L}), \mathrm{UNa}: 49 \mathrm{mEq} / \mathrm{L}(\mathrm{mmol} / \mathrm{L})$, Uosm: 354 mOsm $/ \mathrm{kg}$ (mmol/kg), Posm: 240 mOsm/kg (mmol/ 
kg), BP: 148/78 mm Hg, HR: 90 bpm and RR: 14. The patient was afebrile. Dehydration was suspected secondary to inadequate fluid replacement postoperatively and profuse vomiting. An infusion of $3 \%$ saline was begun at $50 \mathrm{~mL} / \mathrm{h}$. A repeat CT scan of the head was unchanged. Over the first $6-8 \mathrm{~h}$ of 3\% saline administration, the patient became increasingly anxious and agitated with muscle spasms and tremors of the extremities. The rate of rise of serum $\mathrm{Na}$ was $1.1 \mathrm{mEq} / \mathrm{L} / \mathrm{h}$ $(\mathrm{mmol} / \mathrm{L} / \mathrm{h})$. The agitation and nausea eventually subsided. On the morning of day 7 the serum Na was $131 \mathrm{mEq} / \mathrm{L}(\mathrm{mmol} / \mathrm{L})$, indicating a rate of rise of $1 \mathrm{mEq} / \mathrm{L} / \mathrm{h}(\mathrm{mmol} / \mathrm{L} / \mathrm{h})$. The patient was changed to $0.9 \%$ saline and received 6 - 7 L over the next $36 \mathrm{~h}$. He had taken no nourishment in the 7 days after the initial injury, and he reported difficulty sleeping. Subsequent serum sodium values were $126 \mathrm{mEq} / \mathrm{L}(\mathrm{mmol} / \mathrm{L})$ on day 8 and 129 $\mathrm{mEq} / \mathrm{L}(\mathrm{mmol} / \mathrm{L})$ on day 9 . The patient was discharged home with instructions for bed rest, liberal dietary salt intake and fluids as needed.

The patient again developed severe nausea, vomiting, and headaches without observed seizure activity. Upon readmission on day 10, his examination showed serum Na: $110 \mathrm{mEq} / \mathrm{L}$ $(\mathrm{mmol} / \mathrm{L}), \mathrm{Cl}: 76 \mathrm{mEq} / \mathrm{L}(\mathrm{mmol} / \mathrm{L}), \mathrm{K}: 4.9 \mathrm{mEq} / \mathrm{L}(\mathrm{mmol} / \mathrm{L})$, $\mathrm{CO}_{2}: 23 \mathrm{mEq} / \mathrm{L}(\mathrm{mmol} / \mathrm{L}), \mathrm{BUN}: 7 \mathrm{mg} / \mathrm{dL}(2.49 \mathrm{mmol} / \mathrm{L})$, Scr: $0.6 \mathrm{mg} / \mathrm{dL}(53.0 \mu \mathrm{mol} / \mathrm{L})$, Uosm: $304 \mathrm{mOsm} / \mathrm{kg}(\mathrm{mmol} /$ $\mathrm{kg}$ ), UNa: $49 \mathrm{mEq} / \mathrm{L}$ (mmol/L), Posm: $229 \mathrm{mOsm} / \mathrm{kg}$ (mmol/ $\mathrm{kg}$ ), BP: 150/90 mm Hg and HR: $90 \mathrm{bpm}$. In addition, lethargy and mild photophobia were noted. A cosyntropin test indicated normal adrenal responsiveness, ruling out adrenal insufficiency. SIADH was suspected and confirmed with further evaluation, revealing Posm: $220 \mathrm{mOsm} / \mathrm{kg}(\mathrm{mmol} / \mathrm{kg})$ and Uosm: $310 \mathrm{mOsm} / \mathrm{kg}$ ( $\mathrm{mmol} / \mathrm{kg})$.

The patient was placed on $1 \mathrm{~L} /$ day fluid restriction. An infusion of $3 \%$ saline was started at $50 \mathrm{~mL} / \mathrm{h}$ for $2 \mathrm{~h}$ then reduced to $35 \mathrm{~mL} / \mathrm{h}$ for the following $24 \mathrm{~h}$. At this time the $3 \%$ saline infusion was reduced to $20 \mathrm{~mL} / \mathrm{h}$ until it was stopped at approximately 12 noon on day 12 . Serum $\mathrm{Na}$ values were 114 $\mathrm{mEq} / \mathrm{L}(\mathrm{mmol} / \mathrm{L})$ on day 10 and $115 \mathrm{mEq} / \mathrm{L}(\mathrm{mmol} / \mathrm{L})$ on day 11 , and they subsequently stabilized in the low 120 s for the next several days. A magnetic resonance imaging (MRI) of the brain, with and without contrast, was performed on day 13 and was unremarkable. Specifically, no pituitary mass was identified. The patient regained his appetite, and his serum sodium slowly rose to $131 \mathrm{mEq} / \mathrm{L}(\mathrm{mmol} / \mathrm{L})$ with a Posm: $268 \mathrm{mOsm} /$ $\mathrm{kg}$ (mmol/kg), Uosm: $843 \mathrm{mOsm} / \mathrm{kg}$ (mmol/ $\mathrm{kg})$ and UNa: 123 $\mathrm{mEq} / \mathrm{L}(\mathrm{mmol} / \mathrm{L})$ by discharge on day 16 . Discharge therapy was demeclocycline $300 \mathrm{mg}$ orally every $12 \mathrm{~h}$ and a $2 \mathrm{~L} /$ day fluid restriction for approximately 1 month. The SIADH resolved completely within 6 months without further incident.

\section{Discussion}

Typical causes of SIADH include malignancy, tuberculosis, pneumonia, and several drugs (e.g., selective serotonin reuptake inhibitors (SSRIs), carbamazepine) as well as acute cranial insults associated with significant findings of injury or due to neurosurgical procedures. Because most information about post-injury SIADH derives from a patchwork of case reports, the precise risk is difficult to predict. This is the first case to be reported of severe and sustained SIADH resulting from a concussion with brief loss of consciousness but without any evidence of additional injury. This presented a quandary, initially resulting in misdiagnosis and improper treatment. The only other head-injury-related reports available in the literature describe patients sustaining head injury severe enough to cause skull fractures, intracranial hematomas, subarachnoid hemorrhages, and/or Glascow coma scale scores of $<12$ [710]. Our patient had none of these findings, and without severe head injury, SIADH was not initially considered as a cause of his hyponatremia.

The diagnosis was not made until he presented for the second time with severe hyponatremia with measurements of serum Na: $110 \mathrm{mEq} / \mathrm{L}$ (mmol/L), urine $\mathrm{Na}: 49 \mathrm{mEq} / \mathrm{L}$ (mmol/L) and plasma and urine osmolalities of 229 and $304 \mathrm{mOsm} / \mathrm{kg}$ (mmol/kg), respectively.

A few instances of SIADH associated with closed head trauma have been reported. A 68-year-old female with closed head injury from a motor vehicle accident, having a skull fracture, subdural hematoma, subarachnoid hemorrhage and cerebral contusions, manifested SIADH with asymptomatic hyponatremia and without clinical deterioration [9]. In a study of 1,812 consecutive patients with mild closed head injury, only two developed hyponatremia, and both of these patients had documented intracranial hemorrhage [10]. In a similar study of 1,808 patients with head injury, $0.6 \%$ of 842 patients defined as having mild head injury, developed SIADH [11]. The authors of this study defined mild head injury as including at least a linear skull fracture.

Our patient differed in that although there were no physical findings of significant head injury, he nevertheless developed severe symptoms of hyponatremia. This patient is the only reported case of mild head trauma with severe symptomatic hyponatremia, posing concerns that SIADH may go unrecognized in the absence of an established risk factor.

\section{Conclusion}

We report a case of closed head trauma inducing a concussion without further evidence of head injury resulting in severe, symptomatic, and potentially life-threatening hyponatremia. This case underscores the point that mild closed head injury without structural damage should be considered as a cause of SIADH in patients who subsequently develop hyponatremia.

\section{Acknowledgement}

Thanks are given to Pink Folmar, MD, FACP for his contribution in the care of the patient.

\section{Conflict of Interest}

Drs Henderson and Thompson do not have formal affiliations that would present conflicts of interest. 


\section{Abbreviations}

CSW: cerebral salt wasting syndrome; CT: computerized tomography; MRI: magnetic resonance imaging; PCA: patientcontrolled analgesia; SIADH: syndrome of inappropriate antidiuretic hormone; SSRI: selective serotonin reuptake inhibitor

\section{References}

1. Albanese A, Hindmarsh P, Stanhope R. Management of hyponatraemia in patients with acute cerebral insults. Arch Dis Child. 2001;85(3):246-251.

2. Coenraad MJ, Meinders AE, Taal JC, Bolk JH. Hyponatremia in intracranial disorders. Neth $\mathrm{J}$ Med. 2001;58(3):123-127.

3. Kim DK, Joo KW. Hyponatremia in patients with neurologic disorders. Electrolyte Blood Press. 2009;7(2):5157.

4. Born JD, Hans P, Smitz S, Legros JJ, Kay S. Syndrome of inappropriate secretion of antidiuretic hormone after severe head injury. Surg Neurol. 1985;23(4):383-387.

5. Donati-Genet PC, Dubuis JM, Girardin E, Rimensberger
PC. Acute symptomatic hyponatremia and cerebral salt wasting after head injury: an important clinical entity. J Pediatr Surg. 2001;36(7):1094-1097.

6. Sivakumar V, Rajshekhar V, Chandy MJ. Management of neurosurgical patients with hyponatremia and natriuresis. Neurosurgery. 1994;34(2):269-274; discussion 274.

7. Moro N, Katayama Y, Igarashi T, Mori T, Kawamata T, Kojima J. Hyponatremia in patients with traumatic brain injury: incidence, mechanism, and response to sodium supplementation or retention therapy with hydrocortisone. Surg Neurol. 2007;68(4):387-393.

8. Zhang W, Li S, Visocchi M, Wang X, Jiang J. Clinical analysis of hyponatremia in acute craniocerebral injury. $\mathrm{J}$ Emerg Med. 2010;39(2):151-157.

9. Ishibashi A, Yokokura Y. Asymptomatic hyponaturemia in a patient with mild head injury due to syndrome of inappropriate diuretic hormone--a case report. Kurume Med J. 1999;46(2):123-125.

10. Lee ST, Liu TN, Wong CW, Yeh YS, Tzaan WC. Relative risk of deterioration after mild closed head injury. Acta Neurochir (Wien). 1995;135(3-4):136-140.

11. Doczi T, Tarjanyi J, Huszka E, Kiss J. Syndrome of inappropriate secretion of antidiuretic hormone (SIADH) after head injury. Neurosurgery. 1982;10(6 Pt 1):685-688. 